FACULTY OF AGRICULTURE

\title{
ATTEMPTS TO ASSESS THE ROLE OF SOME BIOCONTROL AGENTS IN REDUCING CORN FUNGAL INFECTION AND IMPROVING ITS GROWTH PARAMETERS
}

\author{
Medhat S. Abd-Rabboh ${ }^{1}$ and Yasser M. Abdel-Shafea ${ }^{2 *}$ \\ ${ }^{1}$ Plant Pathology Research Institute, (ARC) Giza, Egypt. \\ ${ }^{2}$ Regional Center for Food and Feed (RCFF), Agricultural \\ Research Center (ARC), Giza, EGYPT. \\ *Correspondence: E-mail:Yasser_773@hotmail.com
}

Received: 12June (2021) Accepted: 20September (2021)

\section{ABSTRACT}

Fungal and bacterial plant diseases cause major losses in agricultural activities and food production through damaging plants and/or crops. This study was conducted to evaluate the antagonistic effect of some fungal, bacterial and yeast biocontrol agents (BA) (Trichoderma harzianum, Pseudomonas fluorescens, mycorrhizae Glomus sp. and Saccharomyces serivisae ) and a mixture of them against damage of corn (Zea mays L.) caused by three isolates of Fusarium moniliforme. In the current experiment, significant reduction in the disease incidence such as number of infected plants and ears was observed in BA treatments in comparison with untreated control accompanied with enhancement of growth features such as plant height and weight, root length and weight and average weight of ears. The obtained results revealed that applying of Mycorrhizae Glomus sp. and Sacchromyces serivisae (Yeast) together showed significant superior effect to reduce diseases incidence and improving growth parameters followed by the BA mixture then Trichoderma harzianum and Pseudomonas fluorescens, respectively. Treatments increased peroxidase and polyphenol oxidase in corn leaves. Mycorrhizae was the most effective in this respect.

Key words: Biocontrol agents (BA), Fusarium moniliforme, Corn, Mycorrhizae, oxidase enzymes, Pseudomonas fluorescens, Trichoderma harzianum and Yeast. 


\section{INTRODUCTION}

Maize (Zea mays L.), also called corn, it is believed to have originated in central Mexico 7000 years ago, it is grown throughout the world. It has been recognized worldwide as a major energy feed ingredient in the diets of poultry (Dei, 2017). About 65\% of the corn grown worldwide is used for livestock feed (FAO, 2005). The stalks, leaves and immature ears are used as forage for ruminants (Leonard and Martin, 1963). Corn is recognized as giving the highest conversion of dry matter into meat, milk and eggs in relation to other cereal grains (Kling, 1991). Corn was considered as the third highest important staple food crop after wheat and rice by area and production in Egypt which grown in the summer or at late-summer. In Egypt, the total cultivated area of corn in 2018 was, about 1.05 million hectares (Agricultural Statistics, 2019). Its production is estimated to increase by 161 million ton to 1.2 billion ton by 2027 (OECDFAO 2018). Corn is subjected to various types of diseases, mainly caused by fungi which minimize the quality of grains and may also produce mycotoxins that cause significant health hazards in humans and animals $(\boldsymbol{L i}$ et al., 2019). Mathur and Manandhar (2003) listed several fungi on corn seeds as seed-borne in different countries, which include 82 species belonging to 43 genera; they added that in Egypt, Fusarium moniliforme and species of Aspergillus, Penicillium and Rhizopus. Fusarium ear rot and root rot and wilt are severe diseases caused by $F$. oxysporum and other Fusarium spp. which is the most destructive abundant disease associated with corn grains worldwide (Lakshmanan and Slevaraj, 1986 and Leslie and Summerell, 2006). In Egypt there are several plant diseases such as common smut, leaf blights, ear rot, stalk rot, bacterial stalk rot and late wilt. Fungal disease is the most important disease that affects the yield crop and cause considerable damage under the Egyptian conditions. Yield losses of susceptible plant may reach about $40 \%$ of the grain yield (Samra et al., 1972). It reduces output in corn by $10 \%$ typically and by $30-50 \%$ in severely affected areas, which characterized by discolored and a reduced number of grains, yield as well as the quality of the seeds (Gai et al., 2018). Pathogens can be survived in infected corn seed without causing apparent symptoms or killing seed tissues (by producing toxic molecules and lytic enzymes) and subsequently transmitted to growing seedlings causing blights and root, stem and ear rot diseases. Under field conditions, the pathogen is systemically transmitted easily through infected seeds to corn growing seedlings by transmitting through stalk up to the ear (Thompson and Raizada, 2018). Controlling corn diseases with chemical fungicides become a not good choice. Using of fungicides is costly, dangerous for human, animal health and environmentally toxic therefor strict regulations on using chemical pesticide and a pressure to remove the most hazardous chemicals from the market were developed (Abd-Rabboh, 2006 and Al-Huqail et al., 2019). The application of biocontrol agents (BA) as antagonistic microorganisms has proved to be 
successful for controlling various plant diseases in many countries (Sivan, 1987). It can serve as the best control measure under greenhouse conditions. Trichoderma spp. were well documented as effective BA of plant diseases caused by soil-borne fungi (Sivan and Chet, 1986, Whipps and Lumsden, 2001 and McLean et al., 2004). BA was considered as a safe environmental application which increase food production and decrease the use of chemical fertilizers, pesticides, and other artificial supplements (Esitken et al., 2005; Bhattacharyya and Jha, 2012). Bacteria isolated from plant rhizosphere or rhizobacteria such as Pseudomonas fluorescens and its pathogenic antagonistic role has been studied for decades (Boddey et al., 1995). These associative bacteria are considered as plant growth-promoting rhizobacteria because of their ability to stimulate plant growth through mechanisms such as biological $\mathrm{N}$ fixation, growth-regulating substance production, mineral and nutrient solubilization, increased root volume, and systemic induction of pathogen resistance (Dobbelaere et al., 2003). The most important mechanism of Trichoderma spp. is the induction of plant defense response to specific pathogens (Harman 2006; Inayati et al. 2020). Other than chemical and physical obstructions, plants have immune systems. The system is able to identify pattern that contain common structural features of all microbes but not present in their host plants. The defense response of plants is rapid, transitory and generalized. During biotic stress, host plant shows various cellular and physiological changes such as ion influx across the plasma membranes; activation of nitric oxide, defense-related genes; high production of ROS (reactive oxygen species), different phytohormones; biosynthesis of specific stress related proteins and production of antimicrobial chemicals such as phenolics (Wu et al. 2014; Nishad et al. 2020). Different biocontrol organisms may cause distinct molecular and cellular transformations in plants that enhance the resistance to biotic and abiotic stress (Brotman et al. 2013; Kumar 2013). The activity of defense-related enzymes such as polyphenol oxidase (PPO) and peroxidase (PO) progressively enhanced in plants when inoculated with $T$. viride alone or in combination with Pseudomonas fluorescens against $M$. phaseolina (Thilagavathi et al. 2007). PO enzymes have been involved in the production of highly toxic compounds that are antifungal in nature, in the production of melanin and melanin like pigments $(\boldsymbol{L i}, \mathbf{1 9 8 1})$ The PO, and PPO enzymes are responsible for the production of phenolic compounds which contribute to the reinforcement of cell barriers (Souguir et al. 2011)

Arbuscular Mycorrhizae (AM) is a nonpathogenic fungi which has a symbiotic relationship with plant root, formed by nearly all terrestrial plants roots and characterized by bidirectional transfer of nutrients between the plants and associated fungi, where plants provide sugar to the fungi and these help the plants on the acquisition of mineral nutrients from the soil (Smith and Barker 2002). AM increase uptake of organic and inorganic phosphorus from the soil and also, uptake of some trace elements like zinc and copper (Oudeh et al., 2002), potassium and magnesium (Sharma et al., 2002) Several studies 
indicated that AM can stimulate plant growth (Gill et al., 2002) and crops yield production (Xavier and Germida, 2002) by increasing the absorption of plant nutrition that is not normally available to non-mycorrhizael plants (Clark, 2002). Hyphae of AM fungi are considered to contribute to soil structure by increasing aggregates and their stability (Caravaca et al., 2002), soil fertility (Eriksson, 2001) and soil reclamation (Barea et al., 1996). The objective of this study was to evaluate the ability of some antagonistic fungal and bacterial agents (Trichoderma harzianum, Pseudomonas fluorescens, Glomus sp., Saccharomyces serivisae and a mixture of them) to improve the growth and yield of corn and decrease the plant infection caused by three isolates of Fusarium moniliforme fungal corn pathogens under open greenhouse conditions.

\section{MATERIALS AND METHODS}

Plant materials:

Corn (Zea mays L.) seeds of local maize cultivar (Three ways cross 310) were used in this study from central administration for seeds agricultural research center (ARC), Giza, Egypt.

\section{Isolation and identification of the pathogenic organisms:}

The casual pathogenic organisms were isolated from naturally infected corn samples collected from three different districts (El Monofeya, El Sharkia and Pany souief) and labeled as Fusarium moniliforme (1,2 and 3). Samples were surface sterilized with alcohol and flamed. The cortex was peeled off and small pith was cut aseptically and plated on potato Dextrose agar (PDA) medium supplemented with $0.1 \%$ yeast extract and incubated at $30^{\circ} \mathrm{C}$ for 5 days. Hyphal tip and single spore techniques were applied for fungal purification the isolates were sub cultured on PDA medium. The isolates were identified using cultural characteristics and morphology with reference to De Hoog et al. (2000) and Jay (1998).

\section{Biological control:}

\section{Isolation of the BA (Biocontrol Agents) microorganisms:}

Healthy plants from epidemic fields were carefully uprooted and their roots were separated, transferred to sterile container and shaken to remove the excess soil from the root surfaces. One gram of soil dried in oven at $120{ }^{\circ} \mathrm{C}$ for two hours, then used for isolation of biocontrol agents by adding in a test tube with $10.0 \mathrm{ml}$ sterile distilled water (SDW) to give $1 \times 10^{-1}$ and diluted to $1 \times 10^{-6}$. For microbial isolation one $\mathrm{ml}$ from each of the following suspensions i.e., $1 \mathrm{x}$ $10^{-1}, 1 \times 10^{-2}, 1 \times 10^{-3}, 1 \times 10^{-4}, 1 \times 10^{-5}$ and $1 \times 10^{-6}$ was poured in Petri dishes contained (PDA) medium. Suspensions were separated on the medium surface and the supernatant was eliminated and then incubated at $29^{\circ} \mathrm{C}$. Bacterial isolates were transferred after 24 to $48 \mathrm{hr}$., whereas fungal isolates were transferred after 3-5 days. The isolated biocontrol fungal isolates were identified according to the description given by Rifai (1969). Bacterial isolates were 
identified at Bacterial Diseases Department, Plant Pathology Institute. Agricultural Research Center Giza-Egypt.

\section{Pathogenicity test:}

For preparation of the fungal inoculate to the pathogenicity test, sorghum grains were washed, filled in 1.0 liter bottles at the rate of $250 \mathrm{~g} / \mathrm{bottle}$, then moistened with suitable amount of tap water and then autoclaved at $1.5 \mathrm{~kg} / \mathrm{Cm}^{2}$ for 30 min., sorghum grain medium was inoculated with pathogenic fungi isolates (Fusarium moniliforme). Each isolate was inoculated in ten bottles and incubated at $30{ }^{\circ} \mathrm{C}$ for 20 days. The inoculum of each isolate was mixed with autoclaved soil [at the rate of 3: $100(\mathrm{w} / \mathrm{w})$, four pots were assigned for each treatment, and each pot was planted with five seeds of the obtained cultivar. Four un-inoculated pots were assigned for check treatment sown at the same rate.

\section{Laboratory experiment:}

Relationship between the causal pathogenic fungi $F$. moniliforme isolates (1, 2 and 3) and BA (Trichoderma harzianum, Pseudomonas fluorescens) were studied. Petri dishes ( $9 \mathrm{~cm}$ in diameter) containing PDA medium were used in these trials. Five mm discs of six days old culture of 3 pathogenic fungi isolates were inoculated onto peripheral side of the PDA plate and same diameter disc of 5 days-old culture of the tested BA were inoculated onto the other side of the plate. Plates were incubated at $30 \mathrm{C}^{\circ}$ for 6 days. The radial growth of pathogenic fungi was measured at two dimensions and then mean were estimated in $\mathrm{mm}$.

\section{Pathogenicity test of the causal fungi against corn in pots.}

\section{A. Under field conditions:}

Effect of three BA (T. harzianum, P. fluorescens Mycorrhizae Glomus spp. and Saccharomyces cerevisiae) and a mixture of them on corn under field conditions were studied. These experiments were conducted at Zennara, Tala, Monofia at the $4^{\text {th }}$ week of May 2020. Ten m long $75 \mathrm{~cm}$ row spacing, $25 \mathrm{~cm}$ between hills and 2-3 seed/hill. 4 rows each one contain 100 plants on row for each treatment. Results were collected after 45 days and 90 days.

\section{B. Under greenhouse condition:}

In this experiment, 4 pots were used for each treatment and five seeds of Trihybrid 310 corn seeds were cultivated in each pot $(30.0 \mathrm{~cm}$ in diameter) and sown in each pot. The tested fungi were grown on sterilized sorghum grains as mentioned before. The tested inoculum of both pathogens and the biocontrol fungi were prepared by mixing each of them at the rate $1: 1(\mathrm{w}: \mathrm{w})$ then added to autoclaved soil at rate of 3\%, 15 days before sowing. Results were obtained and investigated after 80 days. While bacterial strain inoculated in liquid pepton medium $200 \mathrm{ml} / 50 \mathrm{ml}$ flask) and incubated at $27^{\circ} \mathrm{C}$ for 5 days. The inoculum was added to the potted soil at the rate of 1 flask per pot $(2 \times 107 \mathrm{cell} / \mathrm{ml}), 15$ days before sowing.

\section{Disease control using} mycorrhizae:

Isolation and identification of vascular arbuscular mycorrhizae spores: 
Soil samples were collected from rhizoplane of different crops. 100 gram soil sample was first stirred thoroughly in a bucket containing $5 \mathrm{~L}$ water and then allowed to settle for $15 \mathrm{sec}$. through $0.5 \mathrm{~mm}$ sieve into a second bucket, in which the suspension was swirled vigorously and again allowed to settle for another $15 \mathrm{sec}$. , the supernatant was poured through a $0.036 \mathrm{~mm}$ sieve and the trapped material was washed into a beaker. After stirring, the material was transferred to $100 \mathrm{ml}$ centrifuge tubes and centrifuged for 4 minutes at 3000 $\mathrm{rpm}$. The supernatant was replaced with $5 \%$ sucrose solution. The tubes were stirred and then centrifuged for 15 seconds at $3000 \mathrm{rpm}$. The resulting supernatant was poured through a $0.036 \mathrm{~mm}$ sieve and finally the residue on the sieve was washed with water to remove the sucrose solution. The residue was washed into petri dishes and examined under a binuclear microscope. The isolated fungi were identified according to Gerdeman and Trappe (1979).

\section{Preparation of mycorrhizael inoculum:}

A mycorrhizal fungal inoculum belonging to Glomus genera was prepared by embedding in agar water medium in petri dishes. Agar medium which carries mycorrhizal spores of every petri dish was divided to small pieces $1 \mathrm{~cm}^{2}$, each piece was inoculated to each pot. Five gm of yeast (Saccharomyces cerevisiae) containing $5 \times 10^{12}$ yeast cells were applied together with $\mathrm{AM}$ to stimulate the growth of corn.

\section{Effect of mycorrhizae against three of causal pathogenic fungi in greenhouse:}

A pot experiment was conducted in corn disease department, agricultural research center, Giza, Egypt. Pots [30 $\mathrm{cm}$ in diameter] were filled with Nile silt soil, previously individual infested with the tested pathogenic fungi were used. Two pieces of water agar medium (contained 60 Chlamydospores of mycorrhizal fungus) were added to each pot. Control treatment was carried out without adding the Chlamydospores. Six corn seeds were sown at each pot. Infection percentage was calculated after 80 days from sowing.

\section{Determination of some} physiological characters

Peroxidase (PO) activity:

The procedure for determining the activity of peroxidase was adopted from Fehrmann and Dimond (1967). Approximately $0.5 \mathrm{~g}$ fresh leaves of treated or non-treated (control) corn leaves ground in a pre-chilled mortar with $0.1 \mathrm{M}$ ice cold phosphate buffer $(20 \mathrm{~mL})$ at $\mathrm{pH}$ 7.1. Later on, it was kept for centrifugation $(3000 \mathrm{rpm})$ for $15 \mathrm{~min}$. The supernatant $(25 \mathrm{~mL})$ was used for assay. Freshly prepared pyrogallol, reagent, enzyme extract and phosphate buffer were mixed in a cuvette tube and the blend was tuned to zero absorbance on a spectrophotometer. The activity of enzyme was measured as the alteration in absorbance per minute $(\Delta \mathrm{A} / \mathrm{min})$ at $430 \mathrm{~nm}$.

\section{Polyphenol oxidase (PPO):}

Enzyme extract $(0.5 \mathrm{~mL})$ and $0.1 M$ phosphate buffer $(2.3 \mathrm{~mL})$ were added to a cuvette, which was adjusted to zero absorbance on a spectrophotometer 
(Mahadevan and Sridhar 1982). A $0.2 \mathrm{~mL}$ aliquot of $0.1 M$ catechol was added and then reactants were rapidly mixed. The activity of enzyme was noted as variation in absorbance instantaneously after adding $0.1 M$ catechol $(0.2 \mathrm{~mL})$.

\section{Physiochemical analysis of soil:}

Soil samples were taken from $30 \mathrm{~cm}$ depth then air-dried and sieved $(<2$ $\mathrm{mm}$ sieve) before analyses. Soil $\mathrm{pH}$ was measured in deionized water $(1: 1 \mathrm{w} / \mathrm{v})$ with a $\mathrm{pH}$ meter (Orion, 710A), while electrical conductivity (EC) was measured in a 1:5 soil:water solution with an EC-meter (Orion, 5 star) (APHA, 2005). Inorganic anions (Phosphate, sulphate, chloride, nitrate and nitrite concentrations (mg/L) were determined according to (USEPA 300, 1993 \&USEPA 300.1, 1997) by using Thermo Scientific Dionex ICS-5000+ Ion Chromatography supplied with Dionex, Ion Pac AS23 analytical column protected by Dionex Ion Pac AS 23 guard column.

\section{Statistical analysis:}

All experiments were set up in a complete randomized design. One-way ANOVA was used to analyze differences between applied treatments and disease incidence. A general linear model option of the analysis system SAS $(\boldsymbol{S A S}, \mathbf{1 9 9 6 )}$ was used to perform the ANOVA. Duncan's multiple range tests at $P<0.05$ level was used for means separation

(Winer, 1971).

\section{RESULTS AND DISCUSSION}

Corn is one of the most important crops all over the world for its essential uses in human consumption, animal feeding and industrial uses. Several fungal diseases infect corn crops from seedling to maturity stages. The majority of them are spread by seeds or transmitted from the soil, resulting in lower grain quality.

\section{1- In vitro laboratory experiment:}

The antagonistic potential of BA was assessed against the fungal pathogens by dual culture assay. The data presented in Table (1) showed that significant reduction in Radial mycelial axis growth of pathogenic fungi $(F$. moniliforme) 3 isolates with a variable ratio after 6 days of incubation at $30^{\circ} \mathrm{C}$ against tested BA (T. harzianum followed by $P$. fluorescens) through creation of an inhibition zone and eventual over-growth. Such findings are consistent with those of Rasmy, 1991 and $X \boldsymbol{u}$ et al., 1999. As compared with control, also, data showed that $T$.harzianum had the greatest reduction zone than that of $P$. fluorescens with all pathogenic fungi. The growth reduction percentages were (89.63, 89.78 and 87$) \%$ for $F$. monilifome (1, 2 and 3 ) respectively. Gomathinayagam et al. (2010) reported that Trichoderma spp. was present in all soil and it was the most cultural fungi. Trichoderma species are strongly antagonistic to other phytopathogenic fungi. They produce hydrolytic enzymes which are believed to play an important role in the parasitism of phytopathogenic fungi. Some bioagents affect the pathogen by producing its metabolites in the medium, such as Tricodermin, Gliotoxin and some other antibiotics. These results are in harmony with those obtained by Pieta and 
Pastucha (1994) and Abd-El-Khairet al. (2011) and Ragab et al. (2015). They reported that, T. album, T.hamatum, T. harizianumand $T$. viride significantly reduced the mycelial growth of $R$. solani. El-Mougy et al., (2013) reported that, $P$. fluorescens and $T$. harzianum reduced the growth area more than 90.6 and $87.4 \%$ for $F$. solani and $R$ solani, respectively. The $P$. fluorescens has been reported by various researchers to restrict the growth of microorganisms causing disease in vitro (Thomashow and Weller, 1988; Hebbar et al., 1992; Rosales et al., 1995). Several mechanisms could be suggested to interpret antagonistic potentiality of the tested antagonists. For example the ability to produce lytic enzymes (Fridlender et al., 1993), antibiotics (Bender et al., 1999), volatile compounds (Claydon et al., 1987; Bakker and Schippers, 1987) and phytotoxic substances (Hoagland and Cutler, 2000). In the case of bacterial antagonists, it has been suggested that associated with the production of antibiotics (Bull et al., 1997 and Janisiewicz et al., 1991).

\section{1- Field experiment}

Data tabulated in Table (2) represent the effect of BA on corn growth parameters (Plant height, root length, root weight and stalk weight) under the field conditions after 45 days of sowing. Data revealed that the most superior effects were obtained by mycorrhizae and S. serivisae together on all growth parameters followed by the BA mixture, then $T$. harzianum, while the least effect was obtained by $P$. fluorescens comparing with control.

After 90 days from sowing, the growth parameters results tabulated in Table (3) were collected as an average of 10 plants revealed that there was a positive correlation between efficiency of BA on plant infection and growth vegetative (plant height and weight) mycorrhizae and $S$. serivisae and BA mixture still have the greatest effect on Plant height $209 \mathrm{~cm}$ and $195.8 \mathrm{~cm}$, respectively and plant weight with $552.2 \mathrm{gm}$ and $552.6 \mathrm{gm}$ respectively followed by $T$. harzianum 522.4 gm for plant weight and $188.4 \mathrm{~cm}$ for plant height then $P$. fluorescens with 501.8 gm for plant weight and $181.2 \mathrm{~cm}$ for plant height comparing with control. Moreover, mycorrhizae and S. serivisae and BA mixture completely prevent plant and ear infections with $0 \%$ followed by $T$. harzianum then P. fluorescens comparing with control. Also, AM and BA mixture showed the best results in number and weight of ears per plant, whereas they gives 3 ears per plant with the greatest average weight with $915 \mathrm{gm} / \mathrm{plant}$ and $930 \mathrm{gm} /$ plant, respectively while the lowest effect was obtained by $P$. fluorescens with $525 \mathrm{gm} /$ plant comparing with control. These results may be attributed to the role of AM fungi in increasing the activities of beneficial soil microorganisms, like $\mathrm{N}$ fixers and $\mathrm{P}$ mobilizers, and microorganisms in plant rhizosphere, and consequentially the uptake of $\mathrm{N}, \mathrm{P}$, and $\mathrm{K}$ promoted plant growth (Karthikeyan et al., 2007, 2008). Morphological root changes in mycorrhizae treated plants led to increasing the absorptive surface area of the whole host root system to water and mineral nutrients supply, 
particularly P, so that can improve biological $\mathrm{N}$-fixation in soil Soliman et al., (2011). The increase in plant biomass by $A M$ inoculation has been reported for perennial medicinal plants like palmarosa and kalmegh (Gupta and Janardhanan, 1991 and Arpana and Bagyaraj, 2007, respectively). Various mechanisms have been suggested for the nutrient uptake by AM plants, including the external hyphae of AM fungi which allow the root system to exploit a greater volume of soil nutrients (i) by extending away from roots and translocating nutrients from some distance to the rhizosphere and (ii) by exploiting smaller soil pores not reached by root hairs and adding surface area to adsorption system (O'Keefe and Sylvia, 1990). Trichoderm spp., a microorganism that can promote plant growth in rhizosphere is known to stimulate

producing growth regulators (Jaleel et al., 2007; Karthikeyan et al., 2010).

\section{2- Greenhouse experiment}

Data in Table (4) clarify that the best results were achieved after 80 days of sowing in green house experiment in reducing the percent of infection caused by the $F$. moniliforme in corn were obtained when applying mycorrhizae and $S$. serivisae together and BA mixture with $0 \%$ against all pathogenic fungi, while antagonistic effects of $P$. fluorescens against $F$. moniliforme 1,2 and 3 gives $(0$, 20 and 20\%) respectively. Thereafter, T. harzianum (15, 20 and 25\%) with the same fungi respectively.

\section{Enzymes activity:}

The antagonistic effect of BA on the activity of PO and PPO enzymes in the infected plants by $F$. moniliforme are illustrated in Table (5). The obtained results showed that $\mathrm{PO}$ and $\mathrm{PPO}$ activity in the infected plants seemed to be higher than that of the healthy plants. The treatment of BA especially mycorhhiza (1.005 and 0.648) significantly induced antioxidant defense enzymes in the plants leaves when compared with the untreated healthy plants, thus this may alleviating $F$. moniliforme oxidative damage and suppressing blast disease incidence. PO and PPO enzymes plays a significant role to initiate the plant defense response against various pathogens through production of highly toxic phenolic compounds and higher production of reactive oxygen species or establishment of structural barriers such as lignin accumulation (Yusnawan et al. 2019; Inayati et al. 2020). 
Table (1): In vitro evaluation of biocontrol agents antifungal activity on radial mycelial growth of $F$. moniliforme.

\begin{tabular}{|c|c|c|c|c|c|c|}
\hline \multirow{2}{*}{ Fungi } & \multirow{2}{*}{$\begin{array}{l}\text { Control } \\
\text { (cm) }\end{array}$} & \multicolumn{2}{|c|}{ P. fluorescens } & \multicolumn{2}{|c|}{ T. harzianum } & \multirow[t]{2}{*}{ LSD } \\
\hline & & $(\mathbf{c m})$ & $\%$ of reduction & (cm) & $\%$ of reduction & \\
\hline F. moniliforme 1 & $8.97 \pm 0.09^{\mathrm{c}}$ & $3.03 \pm 0.03^{\mathrm{a}}$ & 66.22 & $0.93 \pm 0.03^{b}$ & 89.63 & 0.20 \\
\hline F. moniliforme 2 & $9.10 \pm 0.06^{c}$ & $2.80 \pm 0.06^{\mathrm{a}}$ & 69.23 & $0.93 \pm 0.02^{\mathrm{b}}$ & 89.78 & 0.18 \\
\hline F. moniliforme 3 & $9.00 \pm 0.06^{\mathrm{c}}$ & $2.13 \pm 0.03^{\mathrm{a}}$ & 76.33 & $1.17 \pm 0.03^{\mathrm{b}}$ & 87 & 0.15 \\
\hline
\end{tabular}

Within the same row, various superscript letters indicate significant differences (Duncan, $P<0.05$ ), Data are expressing as means \pm SE.

Table (2): Effect of biocontrol agents on corn growth parameters in field after 45 days of sowing.

\begin{tabular}{|l|l|l|l|l|}
\hline \multicolumn{1}{|c|}{ Parameters } & $\begin{array}{l}\text { Plant height } \\
(\mathbf{c m})\end{array}$ & $\begin{array}{l}\text { Root length } \\
(\mathbf{c m})\end{array}$ & $\begin{array}{l}\text { Root weight } \\
(\mathbf{g m})\end{array}$ & $\begin{array}{l}\text { Stalk weight } \\
(\mathbf{c m})\end{array}$ \\
\hline mycorrhiza \& S. serivisae & $91.5 \pm 1.79^{\mathrm{a}}$ & $16.8 \pm 0.37^{\mathrm{a}}$ & $9.56 \pm 0.24^{\mathrm{a}}$ & $107.0 \pm 0.45^{\mathrm{a}}$ \\
\hline P. fluorescens $^{\mathrm{d}}$ harzianum & $85 \pm 0.84^{\mathrm{c}}$ & $15.4 \pm 0.24^{\mathrm{b}}$ & $8.14 \pm 0.51^{\mathrm{d}}$ & $102 \pm 0.51^{\mathrm{c}}$ \\
\hline B. mixture & $82.5 \pm 0.84^{\mathrm{b}}$ & $15.6 \pm 0.24^{\mathrm{b}}$ & $8.28 \pm 0.20^{\mathrm{c}}$ & $104 \pm 0.87^{\mathrm{b}}$ \\
\hline Control & $91.2 \pm 1.67^{\mathrm{a}}$ & $17.2 \pm 0.20^{\mathrm{a}}$ & $9.44 \pm 0.24^{\mathrm{b}}$ & $107 \pm 0.95^{\mathrm{a}}$ \\
\hline LSD & $80.3 \pm 0.89^{\mathrm{d}}$ & $13.6 \pm 0.24^{\mathrm{c}}$ & $7.36 \pm 0.40^{\mathrm{e}}$ & $98 \pm 2.39^{\mathrm{d}}$ \\
\hline
\end{tabular}

Within the same column, various superscript letters indicate significant differences (Duncan, $P<0.05$ ), Data are expressing as means \pm SE. 
Table (3): Corn growth parameters in field after (90 days) from sowing

\begin{tabular}{|c|c|c|c|c|c|c|c|c|c|c|}
\hline \multirow{2}{*}{ Treatments } & \multirow{2}{*}{$\begin{array}{l}\text { Total } \\
\text { plants }\end{array}$} & \multirow{2}{*}{$\begin{array}{l}\text { Plant } \\
\text { height }(\mathrm{cm})\end{array}$} & \multirow{2}{*}{$\begin{array}{l}\text { Plant } \\
\text { weight }(\mathrm{gm})\end{array}$} & \multirow{2}{*}{$\begin{array}{l}\text { Infected } \\
\text { plants } \\
(\%)\end{array}$} & \multirow{2}{*}{$\begin{array}{l}\text { Infected } \\
\text { ears } \\
(\%)\end{array}$} & \multicolumn{5}{|c|}{ Ears } \\
\hline & & & & & & $\begin{array}{l}\text { Ears } \\
\text { No }\end{array}$ & \multicolumn{4}{|c|}{ Average weight of ears (gm) } \\
\hline myco \& S. serivisae & 73 & $209 \pm 0.45^{\mathrm{a}}$ & $552.2 \pm 1.98^{\mathrm{a}}$ & 0.0 & 0.0 & 3 & 380 & 320 & 215 & 915 \\
\hline T. harzianum & 73 & $188.4 \pm 0.51^{\mathrm{c}}$ & $522.4 \pm 1.72^{b}$ & 3 & 1 & 2 & 325 & 210 & - & 535 \\
\hline BA mixture & 73 & $195.8 \pm 0.58^{b}$ & $552.6 \pm 1.60^{\mathrm{a}}$ & 0 & 0.0 & 3 & 370 & 330 & 230 & 930 \\
\hline control & 70 & $171.8 \pm 0.92^{\mathrm{e}}$ & $422.0 \pm 2.10^{\mathrm{d}}$ & 6 & 5 & 2 & 280 & 210 & - & 490 \\
\hline
\end{tabular}

Within the same column, various superscript letters indicate significant differences (Duncan, $P<0.05$ ), Data are expressing as means \pm SE.

Table (4): Infection of $F$. moniliforme isolates on corn plants after 80 days from sowing

\begin{tabular}{|c|c|c|c|c|c|c|c|c|c|c|c|}
\hline \multirow{2}{*}{ Treatments } & \multicolumn{2}{|l|}{ Pot 1} & \multicolumn{2}{|l|}{ Pot 2} & \multicolumn{2}{|l|}{ Pot 3} & \multicolumn{2}{|l|}{ Pot 4} & \multirow{2}{*}{$\begin{array}{l}\text { \% of } \\
\text { survival }\end{array}$} & \multirow{2}{*}{$\begin{array}{l}\% \text { of } \\
\text { infected }\end{array}$} & \multirow{2}{*}{$\begin{array}{l}\% \text { of not } \\
\text { germinated }\end{array}$} \\
\hline & survival & infected & survival & infected & survival & infected & survival & infected & & & \\
\hline mycorrhiza\&yeast & 5 & 0 & 4 & 0 & 4 & 0 & 5 & 0 & 90 & 0 & 10 \\
\hline T. harzianum & 5 & 0 & 5 & 0 & 4 & 1 & 4 & 0 & 90 & 5 & 5 \\
\hline P. fluorescens & 4 & 0 & 5 & 0 & 5 & 0 & 4 & 1 & 90 & 5 & 5 \\
\hline Mix & 5 & 0 & 4 & 0 & 5 & 0 & 4 & 0 & 90 & 0 & 10 \\
\hline mycorrhiza\&yeast\& F.moniliforme1 & 4 & 0 & 4 & 0 & 4 & 0 & 5 & 0 & 85 & 0 & 15 \\
\hline T. harzianum\& $F$. moniliforme1 & 4 & 1 & 4 & 1 & 4 & 0 & 4 & 1 & 80 & 15 & 5 \\
\hline P. fluorescens\& $F$. moniliforme1 & 4 & 0 & 4 & 0 & 5 & 0 & 5 & 0 & 90 & 0 & 10 \\
\hline BA mixture \& $F$. moniliforme1 & 4 & 0 & 4 & 0 & 5 & 0 & 4 & 0 & 85 & 0 & 15 \\
\hline mycorrhiza\&yeast\& $F$. moniliforme 2 & 5 & 0 & 4 & 0 & 4 & 0 & 4 & 0 & 85 & 0 & 15 \\
\hline T. harzianum\& $F$. moniliforme 2 & 3 & 1 & 3 & 1 & 2 & 1 & 3 & 1 & 55 & 20 & 35 \\
\hline P. fluorescens\& $F$. moniliforme 2 & 3 & 1 & 3 & 1 & 3 & 1 & 3 & 1 & 60 & 20 & 20 \\
\hline BA mixture \& $F$. moniliforme 2 & 4 & 0 & 4 & 0 & 5 & 0 & 4 & 0 & 85 & 0 & 15 \\
\hline mycorrhiza\&yeast\& $F$. moniliforme 3 & 5 & 0 & 4 & 0 & 5 & 0 & 4 & 0 & 90 & 0 & 10 \\
\hline T. harzianum\& F. moniliforme 3 & 4 & 0 & 4 & 1 & 3 & 2 & 3 & 2 & 70 & 25 & 5 \\
\hline P. fluorescens\& $F$. moniliforme 3 & 4 & 1 & 3 & 1 & 3 & 1 & 3 & 1 & 65 & 20 & 15 \\
\hline BA mixture \& $F$. moniliforme 3 & 4 & 0 & 4 & 0 & 4 & 0 & 4 & 0 & 80 & 0 & 20 \\
\hline F. moniliforme1 & 2 & 3 & 1 & 4 & 2 & 3 & 1 & 3 & 30 & 65 & 5 \\
\hline F. moniliforme2 & 2 & 2 & 2 & 2 & 2 & 3 & 2 & 3 & 40 & 50 & 10 \\
\hline F. moniliforme 3 & 1 & 3 & 1 & 4 & 1 & 4 & 1 & 4 & 20 & 75 & 5 \\
\hline Control & 2 & 3 & 2 & 3 & 2 & 3 & 2 & 2 & 40 & 55 & 5 \\
\hline
\end{tabular}


Table (5): Effect of biocontrol agents on the activity of some oxidase enzymes in leaves of corn plants infected by $F$. moniliforme samples were taken after 80 days from sowing.

\begin{tabular}{|l|c|c|}
\hline Treatment & $\begin{array}{l}\text { Peroxidase } \\
\text { D.D/gwt a. 3 min. }\end{array}$ & $\begin{array}{l}\text { Polyphenol oxidase } \\
\text { D.D/ gFwt a. 45min }\end{array}$ \\
\hline Mycorrhiza \& Yeast & 1.005 & 0.648 \\
\hline BA mixture & 0.885 & 0.386 \\
\hline Pseudomonas fluorscens & 0.774 & 0.285 \\
\hline Trichoderma harzianum & 0.999 & 0.513 \\
\hline Infected plants & 0.835 & 0.260 \\
\hline Control (halthy plants) & 0.294 & 0.150 \\
\hline L.S.D. at 5\% & 0.866 & 0.0790 \\
\hline
\end{tabular}

Table (6): Chemical properties of soil before the biocontrol agents application (Initial) and at harvest (Final)

\begin{tabular}{|l|l|l|l|l|}
\hline \multirow{2}{*}{ Soil parameters } & \multicolumn{2}{|l|}{ Control } & \multicolumn{2}{l|}{ Biocontrol agents } \\
\cline { 2 - 5 } & Initial & Final & Initial & Final \\
\hline PH & $7.9 \pm 0.0$ & $8.2 \pm 0.0$ & $7.9 \pm 0.0$ & $8.0 \pm 0.2$ \\
\hline EC $\left(\boldsymbol{\mu S ~ c m} \mathbf{~ c}^{-1}\right)$ & $826.0 \pm 46.0^{\mathrm{bc}}$ & $466.0 \pm 98.0^{\mathrm{a}}$ & $697.0 \pm 57.0^{\mathrm{ab}}$ & $1078.0 \pm 98.0^{\mathrm{c}}$ \\
\hline $\mathbf{N o}^{-}(\mathbf{p p m})$ & $306.0 \pm 51.0^{\mathrm{b}}$ & $56.2 \pm 7.3^{\mathrm{a}}$ & $319.0 \pm 45.0^{\mathrm{bc}}$ & $514.0 \pm 87.4^{\mathrm{c}}$ \\
\hline $\mathbf{N o 2}^{-}(\mathbf{p p m})$ & $2.8 \pm 0.3^{\mathrm{b}}$ & $1.1 \pm 0.2^{\mathrm{a}}$ & $4.1 \pm 0.2^{\mathrm{c}}$ & $0.9 \pm 0.1^{\mathrm{a}}$ \\
\hline $\mathbf{C l}^{-}(\mathbf{p p m})$ & $260.0 \pm 29.0^{\mathrm{b}}$ & $40.1 \pm 24^{\mathrm{a}}$ & $251.0 \pm 49.0^{\mathrm{b}}$ & $378.0 \pm 71.0^{\mathrm{c}}$ \\
\hline $\mathbf{P o 4}^{-3}(\mathbf{p p m})$ & $28.3 \pm 0.8^{\mathrm{a}}$ & $29.4 \pm 5.6 \mathrm{a}$ & $12.8 \pm 2.0^{\mathrm{b}}$ & $8.6 \pm 0.9^{\mathrm{c}}$ \\
\hline $\mathbf{S o 4}^{-2}(\mathbf{p p m})$ & $1212.0 \pm 94.0^{\mathrm{c}}$ & $629.0 \pm 380.0^{\mathrm{a}}$ & $981.0 \pm 62.0^{\mathrm{b}}$ & $1216.0 \pm 117.0^{\mathrm{c}}$ \\
\hline
\end{tabular}

Values are the mean \pm standard error $(n=3)$. Means with different superscripts letters in the same row are significantly different $(\mathrm{P}<0.05)$. 
Table (6) shows the soil properties before the BA application (initial) and after harvest (final). The EC values of soils $(876 \mu \mathrm{S} \mathrm{cm}-1$ for control plots and $697 \mu \mathrm{S} \mathrm{cm}-1$ for treated plots); however, significant differences were observed in the final sampling between treatments in which the control and BA plot values decreased $(466 \mu \mathrm{S} \mathrm{cm}-1)$ and increased $(1078 \mu \mathrm{S}$ $\mathrm{cm}-1$ ), respectively. Given that the same volume and quality of irrigation water was applied to all plots, these results suggest that the BA probably promotes salt solubility, especially of chlorides. The $\mathrm{pH}$ values, which ranged from 7.9 to 8.0, were similar during the experiment and were not affected by the BA application. These results are similar to those reported by Mukhtar et al. (2017), who found no differences in $\mathrm{pH}$ after applying phosphate-solubilizing biofertilizer to a wheat crop. According to Chen et al. (2004) and Hayat et al. (2010), rhizobacteria promote phosphate solubilization by increasing the soil available $\mathrm{P}$ concentration. The primary mechanisms of $\mathrm{P}$ solubilization are $\mathrm{H}^{+}$excretion, organic acid production, and acid phosphatase biosynthesis (Behera et al., 2014). Mycorrhiza fungi may infect plants in low Phosphorus soils easier than those in the high-P soils, and fungal species varied in the ability to adapt to different soil P contents (Miller et al., 1995).

Several researches showed the ability of Trichoderma to attack different fungi as shown by Durrell, (1968). Which found that T. harzianum was an effective biocontrol agent for protecting a number of crop plants from damage induced by naturally infested soil with S. rolfsii and $R$. solani under both greenhouse and field conditions. It was capable of directly attacking and lysing both pathogens in culture. Moreover, Elad et al. (1980) found that application of T. harzianum in greenhouse experiments reduced disease incidence in bean seedlings by S. rolfsii up to $97 \%$ and $R$. solani $57 \%$. Also under field conditions, T. harzianum significantly increased the yield and decreased disease incidence. Furthermore, the results obtained by (Elad, 2000a, 2000b) showed that the application of $B$. subtilis and T. harzianum, exhibited a significant antifungal activity (85-100\%) against the fungal molds in vitro and in vivo, depended on isolate and host plant. Antagonistic effect of BA could be inhibit pathogens by antibiosis, some bioactive metabolites, and active degradation-related enzymes, which play crucial roles in inhibiting Botrytis cinerea and Sclerotinia sclerotiorum. Also, Trichoderma spp. may inhibit fungal growth by three mechanisms: competition (for space and nutrients), parasitism (deriving nutrients from the host); and antibiosis (production of an inhibitory metabolite or antibiotic) Harman, (2006). While one mechanism may predominate, this does not exclude the possibility that one or both of the other two mechanisms may also play a role in the antagonistic behavior. Angelica et al. (2001) tested several Trichoderma spp. and reported that all strains produced the enzyme amylase, which is partially responsible for the rapid growth of Trichoderma spp. on potato dextrose broth medium. Trichoderma spp. can also induce systemic and localized resistance as well as directly attacking or inhibiting the growth of plant pathogens (Harman et al., 2004 and Lo et al., 2000). In addition, certain Trichoderma strains have substantial influence on plant growth and development (Hedge and Hofreiter, 1962). In most cases, it is impossible to separate direct effects on plant growth from the control of 
pathogenic or other deleterious microorganisms that reduce plant growth. However, there were reports indicating that Trichoderma spp. could also have the potential to stimulate plant growth independent of any plant disease (Ozbay and Newman, 2004). Windham et al. (1986) concluded that the Trichoderma spp. produced a growthregulating factor which increased the rate of seed germination and dry weight of shoots and stems. Baker (1988) stated that plant growth responses induced by Trichoderma spp. appeared to be due to both the control of minor pathogens and production of a growth-regulating factor. Harman et al. (2004) indicated that Trichoderma spp. have evolved as opportunistic plant symbionts. So, application of T. harzianum in plant production may reduce the use of fungicides, growth regulators and labor which eventually will lower the production costs and environmental impact.

Mycoparasites may produce an array of cell wall lytic enzymes, such as gluconases, chitinases, protease, lipases (Chet, 1987) or antibiotic metabolites such as gliotoxin and glioviridin(Di Pietro et al., 1993). The chitinolytic and glucanolytic enzymes or the combination of lytic enzymes and toxins of the mycoparasites usually act synergistically rather than alone (Chiu and Tzeam, 1995). Singh et al. (2018) found that BA as $P$. fluorescens alleviated stalk rot of sorghum as well augmented plant growth. Use of BA protects environment by avoiding superfluous accumulation of chemicals, preventing residue accretion and pollution. This is supported by results found by Chen et al. (2004) and Hayat et al. (2010), who found that rhizobacteria like $P$. fluorescens promote plant development through mechanisms such as phytohormone production and pathogen biocontrol that help crop development and health.

Among the 3 biocontrol agents tested under both greenhouse and filed conditions, Application of AM fungi and yeast together had the greatest effect on decreasing percentage of plant infection and increase plant growth parameters (Plant height, root length, root weight and stalk weight) simultaneously. AM inoculation increased also, phosphate-solubilizing microorganisms that cause an inhibitory effect on pathogens development through releasing organic acids which are often accompanied with the release of other metabolites, mainly siderophores, phytohormones and lytic enzymes Mukerji and Ciancio (2007) \& Akhtar and Siddiqui (2008). In addition, the increased phenolic compounds, phytoalexins, lignin, phenols, sugars and amino acids (phenylalanine and serine) in mycorrhiza treated plants have been suggested to play an important role in the plant defense mechanism Zhang et al. (2008). AM have a direct effect on root morphology and plant growth through producing some mycorrhizal fungi (indole-acetic acid, gibberellin, Zeatin, Abscisic acid) Ludwing- Muller, 2000 and Liuet al., 2002). The hyphae associated with mycorrhizal plants can ramify a greater soil volume and provide a greater absorptive surface than non-mycorrhizal plants root hairs (Al-Karaki and Hammad, 2001) Some mycorrhizal fungi have the capacity to breakdown phenolic compounds in soil that interfere with nutrient uptake (Bending and Read, 1997). Mycorrhizal fungi reduce plant disease severity through modifying root physiology which may arise through changes in lignin formation (Dugassa et al., 1996). Jeffries and Rhodes (1987) and Elshahat et al., (2010) reported that, the application of AM and yeast together stimulated sweet pepper growth and yield where yeast cells stimulated AM to grow well and increased its 
efficiency to colonize in the root system of plant forming a good symbiotic relationship with plant. Manfred et al. (2006) concluded that dual inoculation of maize with yeast and AM resulted in increased shoot biomass depending on the combination of yeast species and AM isolate.

\section{CONCLUSION}

Our study clearly showed that there is a synergistic effects yielding from combination of both mycorrhiza and yeast together in maize displayed which triggers a stronger defense signals against Fusarium moniliforme, under both greenhouse and field conditions and could reduce the use of chemical fungicide, thereby reduce the hazards to consumers and environment, providing effective way to prevent and control maize fungal disease. Moreover, the use of fungi, bacteria and yeasts showed a great effect on various maize growth parameters and this appear clearly throughout our experiment.

\section{REFERENCES}

Abd-El-Khair, H., R. Kh. M. Khalifa and K. H. E. Haggag, (2011). Effect of Trichoderma species on damping-off diseases incidence, some plant enzymes activity and nutritional status of bean plants. Journal of American Science. 7(1): 156-167.

Abd-Rabboh, M. S. (2006) Studies on late wilt disease of corn. Ph. D. Thesis, Fac. Agri., Minufiya Univ., Minufiya, Egypt; p 114.

Agricultural Statistics (2019) "Ministry of Agricultural and Land Reclamation.

Affairs", Sector. Summer Crops, 3: 52.

Economic

Al-Huqail, A.A., S.I. Behiry, M.Z. Salem, H.M. Ali, M.H. Siddiqui and A.Z. Salem, (2019). Antifungal, antibacterial and antioxidant activities of Acacia saligna (Labill.) HL Wendl. Flower extract: HPLC analysis of phenolic and flavonoid compounds. Molecules, 24(4), 700; 14 pp. 10.3390/molecules24040700.

Akhtar, M.S. and Siddiqui, Z.A. (2008). Arbuscular Mycorrhizal Fungi as Potential Bioprotectants against Plant Pathogens. In: Siddiqui Z.A., M.S. Akhtar and K. Futai (eds.), Mycorrhizae: Sustainable Agriculture and Forestry. SpringerVerlag, Berlin, Germany, pp: 61-97.

Al-Karaki, G. N. and Hammad, R. (2001). mycorrhizal influence on fruityield and mineral content oftomato grown under salt stress. Journal of Plant Nutrition 24(8):1311-1323.

Angelica M, Barbosa G, Rehn KG, Menezes M, Mariano RR. (2001) Antagonism of Trichoderma sp. on CladosporiumHerbarum and their enzymatic characterization. Braz J Microbiol; 32:98-104.

APHA (2005). Standard Methods for the Examination of Water and Waste water, $21^{\text {st }}$ ed. American Public Health Association, Washington, DC, USA. 
Arpana, J. and Bagyaraj, D. J. (2007). Response of kalmegh to an arbuscular mycorrhizal fungus and a plant growth promoting rhizomicroorganism at two levels of phosphorus fertilizer. Am.-Eurasian J. Agr. Environ. Sci. 2: 33-38.

Baker R. (1988) Trichoderma spp. as plant-growth stimulants, CRC Crit Rev Biotechnol: 7, 2:97-106.

Bakker, A.W. and B. Schippers, (1987). Microbial cyanide production in the rhizosphere in relation to potato yield reduction and Pseudomonas spp.mediated plant growth-stimulation. Soil Biol. Biochem. 19: 451-457.

Barea, J.M., Requena, N., Jimenez, I., (1996). A revegetation strategy based on the management of arbuscular mycorrhizas, Rhizobium and rhizobacterias for the reclamation of desertifiedmediterraneanshrubland ecosystems. In: Lasram, M. (Ed.), Calfier Options M6diterran6ennes. Vol. 20, Mycorrhization of Forest Plants Under Arid and Semi-Arid Conditions and Desertification Control in. the Mediterranean Basin. CIHEAM, IAMZ, Zaragoza, pp. 75-86.

Behera, B.C., Singdevsachan, S.K., Mishra, R.R., Dutta, S.K., and Thatoi, H.N. (2014). Diversity, mechanism and biotechnology of phosphate solubilising microorganism in mangrove. A review. Biocatalysis and Agricultural Biotechnology 3:97-110.

Bender, C.L., Rangaswamy, V. and Loper, J. (1999). Polyketide production by plant associated pseudomonads. Annu. Rev. Phytopathol. 37: 175-196.

Bending, G. D. and Read, D. J. (1997). Lignin and soluble phenolic degradation by ectomycorrhizal and ericoid mycorrhizal fungi, Mycological Research, Volume 101, Issue 11,Pages 1348-1354,

Bhattacharyya, P.N., and Jha, D.K. (2012). Plant growth-promoting rhizobacteria (PGPR): Emergence in agriculture. World Journal of Microbiology and Biotechnology 28:1327-1350.

Boddey, R.M., Oliveira, O.C., Urquiaga, S., Reis V.M., Olivares, F.L., Baldani, B.L.D., et al. (1995). Biological nitrogen fixation associated with sugar cane and rice: Contribution and prospects for improvements. Plant and Soil 174:195209.

Brotman Y, Landau U, Cuadros-Inostroza A, Takayuki T, Fernie AR, Chet I, Viterbo A, Willmitzer L (2013). Trichoderma-plant root colonization: Escaping early plant defense responses and activation of the antioxidant machinery for saline stress tolerance. PLoS Pathog 9; Article e1003221

Bull, C.T., Stack, J.P., Smilanick, J.L., (1997), Pseudomonas syringaestrains ESC10 and ESC-11 survive in wounds on citrus and control green and blue molds of citrus. Biol. Control, 8: 81-88.

Caravaca F, Barea JM, Figueroa D, Rolda' NA (2002) Assessing the effectiveness of mycorrhizael inoculation and soil compost addition for reafforestation with Olea europaea subsp. Sylvestris through changes in soil biological and physical parameters. Appl Soil Ecol 20: 107-118.

Chen, Y., Clapp, C.E., and Magen, H. (2004). Mechanisms of plant growth stimulation by humic substances: The role of organoiron complex. Soil Science and Plant Nutrition 50:1089-1095. 
Chet I (1987) Trichoderma. Application, mode of action and potential as a biocontrol agent of soil-borne plant pathogenic fungi. In: Chet I (ed) Innovative Approaches to Plant Disease Control, Willey J, and Sons, New York, pp 137160.

Chiu SC and Tzeam SS (1995) Glucanolytic enzyme production by Schyzophyllumcommunae Fr. during mycoparasitism. PhysiolMol Pl Pathol 46: 83-94.

Clark, R. B. (2002). Differences among mycorrhizal fungi for mineral uptake per root length of switchgrass grown in acidic soil. Journal of Plant Nutrition, 25: $1753-1772$.

Claydon, N., M. Allan, J.R. Hanson, and A.G. Avent, (1987). Antifungal alkyl pyrones of Trichoderma harzianum. Trans. Brit. Mycol. Soc. 88: 503-513.

De Hoog G S, Guarre J and Gene J F (2000), Atlas of Clinical Fungal, 2nd Edition. The Netherland Publishers, pp. 450-453.

Dei, H. K. February 15th (2017). Assessment of Maize (Zea mays) as Feed Resource for Poultry, Poultry Science, MiladManafi, IntechOpen, DOI: 10.5772/ 65363.

Di Pietro AM, Lorito CK, Hayes RM, Broadway, and Harman GE (1993) Endochitinase from Gliocladiumvirens isolation, characterization and synergistic antifungal activity in combination with gliotoxin. Phtopathology 83: 308-313.

Dobbelaere, S., Vanderleyden, J., and Okon, Y. (2003). Plant growth-promoting effects of diazotrophs in the rhizosphere. Plant Science 22:107-149.

Dugassa GD, von Alten H, Schonbeck F. (1996). Effects of arbuscular mycorrhiza (AM) on health of Linumusitatissimum L infected by fungal pathogens. Plant and Soil185, 173-182.

Durrell, L. W. (1968). Hyphal invasion by Trichoderma viride Mycopathol. et Mycol. Appl. 35:138-144.

Elad, Y. (2000a). Biological control of foliar pathogens by means of Trichoderma harzianumand potential modes of action. Crop Protection, 19(8), 709-714.

Elad, Y. (2000b). Trichoderma harzianumT39. Preparation for biocontrol of plant diseases-control of Botrytis cinerea, Sclerotinia sclerotiorum and Cladosporium fulvum. Biocontrol Science and Technology, 10(4), 499-507.

Elad Y, Chet I, Katan J. (1980) Trichoderma harzianum: A biocontrol agent effective against Sclerotium rolfsii and Rhizoctonia solani. Phytopathology. Feb; 70(2):119-121. DOI: 10.1094/phyto-70-119.

El-Mougy, N.S., F.Abdel-Kareem, M.M.Abdel-Kader and Y.O. Fatouh, (2013). Long term effect of applied compost and bio-agents as integrated treatment for controlling bean root rot disease in solarized soil under field conditions. Plant Pathology \& Quarantine 3(1): 41-52.

Elshahat, M.R., Abdelsalam, A. F. and Mohamed R. (2010). Arbuscular mycorrhizae and yeast as biofertilizers for organic farms. J. Biol. Chem. Environ. Sci., Vol. 5(4): 71-87.

Eriksson, A. (2001). Arbuscular mycorrhiza in relation to management history, soil nutrients and plant species diversity. Plant Ecol. 155: 129-137. 
Esitken, A.S., Ercisli, H., Karlidag, L., and Sahin, F. (2005). Potential use of plant promoting rhizobacteria (PGPR) in organic apricot production. p. 90-97. In Libek, A., Kaufmane, E., and Sasnauskas, A. (eds.) Proceedings of Int. Scientific

Conference of Environmentally Friendly Fruit Growing. 7-9 September. Tartu University Press, Tartu, Estonia.

FAO, Food and Agriculture Organization (2005). Statistical Yearbook of FAO. Rome: FAO Publications.

Fehrmann H, AJP Dimond (1967). Peroxidase activity and Phytophthora resistance in different organs of potato plant. J Plant Pathol 57:69-77

Fridlender, M., J. Inbar, and I.Chet, (1993). Biological control of soilborne plant pathogens by a $\beta-1,3$ - glucanase-producing Pseudomonas cepacia. Soil Biol. Biochem. 25: 1211-1221.

Gai, X., H. Dong, S. Wang, B. Liu, Z. Zhang, X. Li and Z. Gao, (2018). Infection cycle of maize stalk rot and ear rot caused by Fusarium verticillioides. PLoS One, Vol. 13. 7. 10.1371.

Gerdeman, J.N. and Trappe, J.M. (1979). The endogonaceae in the pacific Northwest Mycol. Mem., 5:176.

Gill, T.S., Singh, R.S. and Kaur, J. (2002). Comparison of four arbuscular mycorrhizal fungi for root colonization, spore population and plant growth response in chickpea. Indian Phytopathology 55(2): 210-213.

Gomathinayagam, S., Rekha, M., Murugan, S., Jagessar, J.C., (2010). The biological control of paddy disease brown spot (Bipolarisoryzae) by using Trichoderma viride in vitro condition. Journal of Bio. Pesticides, 3, 93-95.

Gupta, M. L. and Janardhanan, K. K. (1991). Mycorrhizal association of Glomus aggregatum with palmarosa enhances growth and biomass. Plant Soil. 131: 261-263.

Harman GE. (2006) Overview of mechanisms and uses of Trichoderma spp. Phytopathology; 96:190-94.

Harman GE, Howell CR, Viterbo A, Chet I, Lorito M. (2004) Trichoderma species opportunistic, avirulent plant symbionts. Nat Rev-Microbiol; 2:43-56.

Hayat, R., Ali, S., Amara, U., Khalid, R., and Ahmed, I. (2010). Soil beneficial bacteria and their role in plant growth promotion. A review. Annals of Microbiology 60:579-598.

Hebbar, K.P., Davey, A.G., Merrin, J., McLoughlin, T.J. and Dart, P.J. (1992). Pseudomonas cepacia, a potential suppressor of maize soil-borne diseasesSeed inoculation and maize root colonization. Soil Biology and Biochemistry, 24 (10): 999-1007.

Hedge JE, Hofreiter BT (1962). In: Methods in carbohydrate chemistry. Whistler RL, Be Miller JN, editors. NewYork: Academic Press.

Hoagland, R.E. and S.J. Cutler, (2000). Plant microbial compounds as herbicides. In: Narwal, S.S., Hoagland, R.E., Dilday, R.H., Reigosa, M.J. (Eds.), Allelopathy in Ecological Agriculture and Forestry. Proceedings of the III International Congress on Allelopathy in Ecological Agriculture and Forestry, 
Dharwad, India, 18-21 August, 1998. Kluwer Academic Publications, London, UK, pp.73-99.

Inayati A, Sulistyowati L, Aini LQ, Yusnawan E (2020). Trichoderma virens-Tv4 enhances growth promoter and plant defense-related enzymes of mungbean (Vigna radiata) against soil-borne pathogen Rhizcoctonia solani. Biodivers $J$ Biol Divers 21:2410-2419

Jaleel, C. A., Manivannan, P., Sankar, B., Kishorekumar, A., Gopi, R., Somasundaram, R. and Panneerselvam, R. (2007). Pseudomonas fluorescens enhances biomass yield and ajmalicine production in Catharanthus roseus under water deficit stress. Colloid. Surface. B. 60: 7-11. Janisiewicz, W., Yourman, L., Roitman, J., Mahoney, N., (1991). Postharvest control of blue mold and gray mold of apples and pears by dip treatment with pyrrolnitrin, a metabolite of Pseudomonas cepacia. Plant Dis., 75, 490-494.

Jay J M (1998), Food Spoilage in Modern Food Microbiology, 4th Edition, Chapman and Hall Inc. New York, p. 195.

Jeffries, P. \& Rhodes, L. H. (1987). Use of Mycorrhizae in Agriculture, Critical Reviews in Biotechnology, 5:4, 319-357,

Junior-Bueno C, Luiz de Souza N. (2003). Impact of soil solarization on the antagonism of fluorescent Pseudomonas spp. to Rhizoctonia solani Kuhn AG 4 HGI. Summa Phytopathologica, 29(2): 147-152.

Karthikeyan, B., Jaleel, C. A., Gopi, R. and Deiveekasundaram, M. (2007). Alterations in seedling vigour and antioxidant enzyme activities in Catharanthus roseus under seed priming with native diazotrophs. J. Zhejiang Univ. Sci. B. 8: 453-457.

Karthikeyan, B., Jaleel, C. A., Lakshmannan, G. M. A. and Deiveekasundaram, M. (2008). Studies on rhizosphere microbial diversity of some commercially important medicinal plants. Colloid. Surface. B. 62: 143145.

Karthikeyan, B., Joe, M. M., Jaleel, C. A. and Deiveekasundaram, M. (2010). Effect of root inoculation with plant growth promoting rhizobacteria (PGPR) on plant growth, alkaloid content and nutrient control of Catharanthus roseus (L.) G. Don. Nat. Croat. 19: 205-212.

Kling IG. (1991) Quality and Nutrition of Maize; IITA Research Guide 33. Ibadan: International Institute of Tropical Agriculture. 1991; p. 9-21.

Kumar S (2013). Trichoderma: A biological control weapon for managing plant diseases and promoting sustainability. Intl J Agric Sci Vet Med 1:106-121

Lakshmanan $P$ and Slevaraj P. (1986). An effective method for the control of Panama disease of banana. In: "Proceeding of Seminar on Management of Soil Borne Diseases of Crop Plants. (Shanmugam N. Ed.)”. Tamil Nadu Agricultural University, Coimbatore. India. pp. 20.

Leonard WH and Martin IH (1963). Cereal Crops. New York: Macmillan Co. p. 131-360.

Leslie, J.F. and Summerell, B.A. (2006). The Fusarium Laboratory Manual. Blackwell Publishing, Ames, IA, USA. Pages: 388. 
Li, C. Y. (1981) Phenoloxidase and peroxidase activities in zone lines of Phellinus weirii. Mycologia, 73, 811-821.

Li, Lina, Qing Qu, Zhiyan Cao, Zhengyu Guo, Hui Jia, Ning Liu, Yanhui Wang, and Jingao Dong. (2019). "The Relationship Analysis on Corn Stalk Rot and Ear Rot According to Fusarium Species and Fumonisin Contamination in Kernels" Toxins 11, no. 6: 320.

Liu, R.; Li, M.; Meng, X.; Liu, X. and Li, X. (2002). Effects of A fungi on endogenus hormones in corn and cotton plants. Mycosystema 19: 91-96.

Lo CT, Liao TF, Deng TC. (2000) Induction of systemic resistance of cucumber to cucumber green mosaic virus by the root colonizing Trichoderma spp. Phytopathology; 90:547.

Ludwing- Muller, J. (2000). Hormonal balance in plants during colonization by mycorrhizal fungi. In: Arbuscular Mycorrhiza. Physiology and function. Y. Kapulnick and D. D. Douds. J. (EDS.). Kluwer Academic Press. Pp. 263-286.

Mahadevan A and Sridhar R (1982). Methods of physiological plant pathology, 2nd Edition. Sivakasi Publication, Madras, India

Manfred, J. G., Püschel, D., Rydlova, J. and Vosa'tka, M. (2006). Effect of inoculation with soil yeasts on mycorrhizal symbiosis of maize. Pedobiologia 50 (2006) $341-345$.

Mathur, S.B. and H.K. Manandhar, (2003). Fungi in seeds: Recorded at The Danish Government Institute of Seed Pathology for Developing Countries. Kandrups Bogtrykkeri, Århusgade, Copenhagen, Denmark.

McLean, K.L., Dodd, S.L., Sleight, B.E., Hill, R.A., Stewart, A., (2004), Comparison of the behavior of a transformed hygromycin resistant strain of Trichoderma atoviride with the wild-type strain. NZ Plant Protect., 57: 72-76.

Miller, M. H., McGonigle, T. P. and Addy, H. D. (1995). Functional ecology of vesicular arbuscular mycorrhizas as influenced by phosphate fertilization and tillage in an agricultural ecosystem. Crit. Rev. Biotechnol. 15: 241-255.

Mukerji, K.G. and A. Ciancio, (2007). Mycorrhizae: The Integrated Pest And Disease Management In: Ciancio, A. and K.G. Mukerji, (eds.), General Concepts in Integrated Pest and Disease Management. Springer, Section 2, pp: 245-266.

Mukhtar, S., Shahid, I., Mehnaz, S., and Malik, K. (2017). Assessment of two carrier materials for phosphate solubilizing biofertilizers and their effect on growth of wheat (Triticum aestivum L.) Microbiological Research 205:107-117.

Nishad R, Ahmed T, Rahman VJ, Kareem A (2020). Modulation of plant defense system in response to microbial interactions. Front Microbiol 11; Article 1298.

OECD-FAO (Organisation for Economic Co-operation and Development) (2018) agricultural outlook 2018-2027. OECD Publishing.

O'Keefe, D. M. and Sylvia, D. M. (1990). Mechanisms of the vesicular-arbuscular mycorrhizal plant growth response. In Arora, D. K., Rai, B., Mukerji, K. G. and Knudsen, G. R. (eds.) Handbook of Applied Mycology. CRC Press, New York. pp. $35-54$. 
Oudeh, M., Khan, A., and Scullion, J. (2002) Plant accumulation of potentially toxic elements in sewage sludge as affected by soil organic matter level and mycorrhizal fungi. :-300. Environ. Pollut. 116 293-300.

Ozbay N, Newman S. E. (2004) Effect of Trichoderma harzianum strains to colonize tomato roots and improve transplant growth. Pak J Biol Sci;7, 2:253-57.

Pieta, D. and Pastucha, A. (1994) Effect of some chemical mordants on Rhizobium phaseoli. Bull. Veg. Crops Res. Work, 42:47-57.

Ragab, Mona M.M., K. A. Abada, L. M. Abd-El-Moneim and Z.AboShoshaYosra, (2015). Effect of different mixtures of some bioagents and Rhizobium phaseoli on bean damping-off under field condition. Inter. J. of Sci. and Eng. Res., 6(7):1009-1106.

Rasmy MR. (1991) Studies on rice diseases in Egypt. Ph.D. thesis, Plant Pathology Dept Fac Agric., Alex Univ Egypt.

Rifai, M. (1969): A revision of the genus Trichoderma. Mycol. Paper 166 Commonw. Mycol. Inst., Assoc. Appl. Biologists, Kew, Surry, England.

Rosales, A.A., Thomashow, L., Cook, R.J. and Mew, T.W. (1995). Isolation and identification of antifungal metabolites produced by rice-associated antagonistic Pseudomonas spp. Phytopathology, 85: 1028-1032.

Samra, A.S., Sabet, K.A., Kamel, M. and Abd El-Rahim, M.F. (1972). Further studies on the effect of field conditions and cultural practices on infection with stalk rot complex of maize. Min. Agri. Techn. Bull, 2.

SAS, (1996) Institute Inc., 'SAS/STAT user's guide. Version 6. Vol. 2.' 12th edn. (SAS Institute Inc.: Cary, NC), 846 pp.

Sharma, S. D., Bhutani, V. P. and Awasthi, R P. (2002). Effect of vesiculararbuscular mycorrhizae and phosphorus on leaf and soil nutrient status of apple seedlings. Indian Journal of Horticulture, 59: 140-144.

Singh, P., Singh, Y., Purohit, J., \&Maharshi, A. (2018). A comparative evaluation of bioagents and chemicals for the control of stalk rot of Sorghum caused by Dickeyadadantii. Journal of Applied and Natural Science, 10(3), 1053-1058.

Sivan, A., (1987), Biological control of Fusarium crown rot of tomato by Trichoderma harzianumunder field conditions. Plant Dis., 71, 587-592. Doi: 10.1094/PD-710587.

Sivan, A. and Chet, I., (1986), Biological control of Fusarium spp. in cotton, wheat and muskmelon by Trichoderma harzianum. J. Phytopathol., 116, 39-47. Doi: 10.1111/j.1439-0434.1986. tb00892.x.

Smith, S. E. and Barker, S. J. (2002). Plant phosphate transporter genes help harness the nutritional benefits of arbuscular mycorrhizal symbiosis. Trends Plant Sci. 7: 189-190.

Soliman, Amira Sh., Shawky, Samaa M., Omar, M.N.A., (2011). Efficency of bioagents in controlling root knot-nematode on Acacia plants in Egypt. American-Eurasian J. Agric. Environ. Sci. 10 (2), 223-229.

Souguir D, Ferjani E, Ledoigt G, Goupil P. (2011) Sequential effects of cadmium on genotoxicity and lipoperoxidation in Vicia faba roots. Ecotoxicology; $20: 329 \pm 36$. 
Thilagavathi R, Saravanakumar D, Ragupathi N and Samiyappan R (2007). A combination of biocontrol agents improves the management of dry root rot (Macrophomina phaseolina) in green gram. Phytopathol Mediterr 46:157-167

Thompson, M.E. and Raizada, M.N. (2018). Fungal pathogens of corn gaining free passage along the Silk Road. Pathogens, 7(4), 81; 16 pp.

Thomashow, L.S. and Weller, D.M. (1988). Role of a phenazine antibiotic from Pseudomonas fluorescens in biological control of Gaeumannomycesgraminis var. tritici. Journal of Bacteriology, 170: 3499-3508.

USEPA Method 300 (1993). "The Determination of Inorganic Anions in Water by Ion Chromatography"; USEPA Cincinnati, Ohio, 1993.

USEPA Method 300.1 (1997). "The Determination of Inorganic Anions in water by Ion Chromatography”, USEPA, Cincinnati, Ohio, 1997.

Whipps, J.M., Lumsden, R.D., (2001), Commercial use of fungi as plant disease biological control agents: status and prospects. p. 9-22. In: "Fungi as Biocontrol Agents: Progress, Problems and Potential" (T.M. Butt, C. Jackson, N. Magan, eds.), (2001), CABI Publishing: Wallingford, UK.

Windham MT, Elad Y, Baker RA (1986). Mechanism for increased plant growth induced by Trichoderma spp., Phytopathology; 76, 5:518-21.

Winer, B.J., (1971) 'Statistical principles in experimental design.' 2nd edn. (McGrawHill Kogakusha Ltd: Tokyo), 596 pp.

Wu S, Shan L, He P (2014). Microbial signature-triggered plant defense responses and early signaling mechanisms. Plant Sci 228:118-126

Xavier LJC and GermidaJJ. (2002). Response of lentil under controlled conditions to co-inoculation with arbuscular mycorrhizal fungi and rhizobia varying in efficacy. Soil BiolBiochem 34: 181-188.

Xu T, Harman GE, Wang YL and Schen Y. (1999) Bioassay of Trichoderma harzianum: strains for control of rice sheath blight. Phytopathology; 89:86.

Yusnawan E, Inayati A, Baliadi Y (2019). Effect of soybean seed treatment with Trichoderma virens on its growth and total phenolic content. In: AIP Conference Proceedings, 2120, No. 1. AIP Publishing LLC, New York, USA

Zhang, L., J. Zhang, P. Christie and X. Li, (2008). Pre-inoculation with Arbuscular mycorrhizael fungi suppresses root knot nematode (Meloidogyne incognita) on cucumber (Cucumis sativus). Biol Fertil. Soils, 45: 205-211. 
محاولات لتقييم دور بعض عوامل المكافحة الحيوية في الحد من الإصابة بفطريات الأذرة وتحسين معايير

$$
\text { مدحت سعيد عبد ربه * و ياسر محمد عبد الثفيع * م }
$$

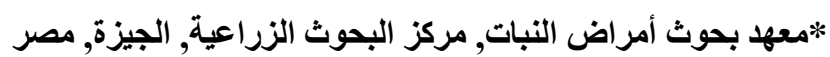
**:المركز الأقليمي للأغذية و الأعلاف, مركز البحوث البحث الزراعية, الجيزة, مصرة, مصر

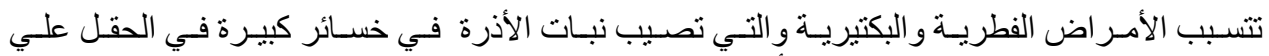

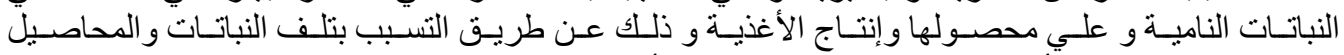

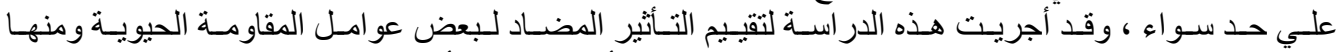
الفطرية و البكتيرية والميكو هيز او الخمبرة وخليط منهم علي الأصابة بتلك الأمر اض. لاض.

(Trichoderma harzianum, Pseudomonas fluorescens, mycorrhiza (Glomus sp.) and Saccharomyces serivise)

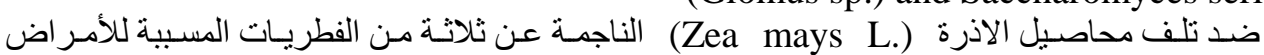

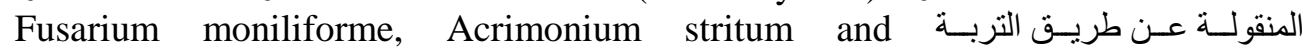
Rizoctonia solani

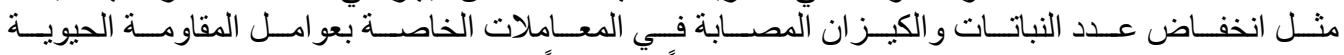

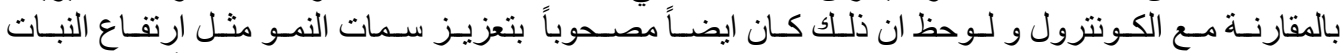

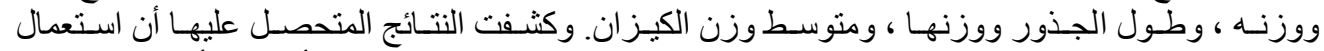
معسا أظهر تأثير انتفوقسا كيبرا

للحـد مـن الإصـابة بـالأمر اض وتحسين سـمات النمـو في نفس الوقت يليـه الخلبط ثنم الاتئي Pseudomonas florescens gharzianum

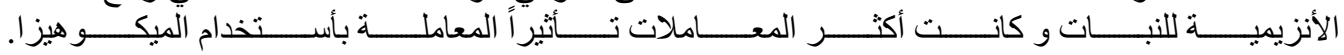


- 107 - 